\title{
SOCIAL POLICIES AND EMOTIONS IN LATIN AMERICA: A THEORETICAL APPROACH TO THEIR ANALYSIS
}

\author{
ADRIÁN SCRIBANO ${ }^{1}$-ANGÉLICA DE SENA ${ }^{2}-$ REBECA B. CENA ${ }^{3}$
}

\begin{abstract}
Millions of subjects living in the Global-South receive benefits from social policies that play a central role in the reproduction of the regime of accumulation. This work critically reflects on the potential links among social policies, world images, and policies of emotions.

In doing so, the following argumentative path is followed: first, we provide a schematic presentation of the link between the regime of accumulation and social policies; second, we briefly introduce the concepts of world images and the politics of emotions; third, we continue by establishing the relationships between the points exposed in the previous sections; finally, we delineate some consequences of the analysis. To conclude, we argue for the need for critically analysis of the constituents of the social policies that 'give shape' to the sociability, life experiences, and sensibilities of millions of 'aided' people and their recursive validation processes.
\end{abstract}

KEYWORDS: Social Policies, World Image, Politics of Emotions, Consumption, Massiveness.

1 Principal Researcher CONICET (Consejo Nacional de Investigaciones Científicas y Técnicas), director of Centro de Investigaciones y Estudios Sociológicos (Center for Sociological Research and Studies), Universidad de Buenos Aires; e-mail: adrianscribano@gmail.com

2 Researcher at Centro de Investigaciones y Estudios Sociológicos. Professor of undergraduate students at Universidad Nacional de Mar del Plata and Universidad de Buenos Aires and Professor of graduate students at Universidad del Salvador; e-mail: angelicadesena@gmail.com

3 Professor at Universidad de Buenos Aires and Universidad Nacional de Mar del Plata. Contact e-mail: rebecena@gmail.com 


\section{INTRODUCTION}

In Latin America, 129 million people ${ }^{4}$ are beneficiaries of Conditional Cash Transfer Programs $\left(\mathrm{CCT}^{5}\right)$. These state interventions are one of the pillars of the development of particular sociabilities, life experiences and sensibilities under the present form of peripheral capitalism.

CCT Programs started being implemented in Latin America, as recommended by the World Bank and the Inter-American Development Bank $^{6}$, in the mid-1990s. The first expressions appeared in Brazil in the form of 'Bolsa Éscola' (1994) and in Mexico as the 'Programa de Educación, Salud y Alimentación Progresa' (1997). According to data provided by Cecchini and Madariaga (2011), in 1997 CCT Programs were present in 3 countries but by 2010 they had been extended to more than 18. Simultaneously, the states were increasing the amounts given, their scope and geographic coverage; in 2010 these programs were assisting more than 25 million Latin American and Caribbean families, reaching $19 \%$ of the population and accounting for $0.40 \%$ of GDP (Stampini \& Tornarolli, 2012).

In general terms, CCT Programs have been defined as state money transfers to households living in poverty; the said transfers are based on the number of children under the age of 18 that live in a household. In return, the state demands of the recipients of the transfer several conditions that aim at strengthening what has been called family human capital. Generally, these conditions which apply to beneficiaries require going through different levels of formal education and job training, on the one hand, and having health care assessments related to having state-mandated vaccinations on the other.

The effect of state interventions made through CCT Programs is greater than that directly materialized through the cash transfers as it also involves the establishment a series of social rules and roles that enable/prevent certain

4 "Most countries that started CCT Programs have maintained and substantially expanded them over the period of analysis. For example, between 2001 and 2010, the number of beneficiaries grew from 22 to 52 million in Brazil, from 16 to 27 million in Mexico, and from 0.4 to 12 million in Colombia" (Stampini and Tornarolli, 2012: 6).

5 According to the Economic Commission for Latin America and the Caribbean (ECLAC) database of non-contributory social protection programs, there were 25 million families engaged in these type of programs, accounting for $0.4 \%$ of regional GDP (Cecchini and Madariaga, 2011).

6 Regarding academic discourse, these CCT Programs have been present in discussions related to poverty reduction strategies, mainly in those promoted by the World Bank, the Inter-American Development Bank, and the Inter-American Social Protection Network (IASPN) within the Organization of American States (OAS) framework. 
emotional behavior. In this sense, CCT Programs are nowadays one of the basic nodes in 'bodies/emotions management'.

From a complementary perspective, every social policy involves a determined world image. A world image implies a way of classifying and dividing the social world. These classifications and divisions become imprinted on the content of social policies. Moreover, these ways of dividing and explaining the world in a particular manner assume that specific characteristics of social matter exist in the practices and narrations of social policies. Accordingly, the reconstruction of a certain world image allows analysis of which matters are recognized as social problems by the state - a process which includes identification of the causes that led to the situation identified as problematic, which solutions are provided, and who is accountable for them. In this context it is possible to understand how social policies are the building blocks of sociabilities and how these are directly linked to the world images they imply.

From a similar perspective that is articulated through the above-described, it is possible to state that social policies 'cause' particular life experiences and sensibilities in the people that are the subjects of such policies. CCT Programs are a prime example of the development of policies of emotions that imply the acceptability processes and reproduction of the state of affairs through social bearability mechanisms and devices for the regulation of sensations which can be identified in world images. CCT Programs subsidize consumption and, through these consumption practices, they produce a set of particular life experiences and sensibilities. Accordingly, it is possible to understand how social policies, the world images imprinted on them, and the associated policies of emotions are some of the central characteristics of current state intervention.

This work undertakes critical reflection on the potential relationships among social policies, world images, and the policies of emotions as elements of the coloniality that affects the current development of the capitalist state in the Global South. ${ }^{7}$

A clearer understanding of the linkages among world images, social policies and policies of emotions in relation to consumption and massiveness allow us to better comprehend the central role of such policies in the development and reproduction of the current regime of accumulation.

7 For a detailed analysis of the relations among coloniality, dependency and empire in the GlobalSouth, cf. Scribano 2012. 


\section{CAPITALISM AND SOCIAL POLICIES}

Current regimes of accumulation require certain mechanisms that are associated with the mode of social and political regulation that control agents' behavior with the aim of making the regime long-lasting (Boyer \& Saillard, 1998). Social policies constitute a central component of the institutions that materialize, produce and reproduce said mechanisms. They not only affect material reproduction processes (by having a direct impact on social possibilities for action through their hold on the distribution of available nutrients), but they also affect the production and reproduction of perceptual schemes that enable some but not other social practices. In other words, they affect the way in which actors behave in different ways; mainly, enabling/blocking the energy that is socially available for action and through the production and reproduction of a series of signifiers and classification devices with the ability to impose perception schemes on subjects in deprived conditions (Corak, Lietz and Sutherland, 2005; Montanari, 2000).

All regimes of accumulation (Harvey, 2004) are made up of specific modes of social and political regulation. In order to last in time, regimes require a mode of regulation that establishes the parameters within which the actors 'are free to' wish, yearn for, act, like, etc. In other words, it is they guarantee a certain predictability in the behavior of actors. The aforementioned predictability adjusts to the norms and rules that affect the regime's validity.

Regulation modes go beyond the formal terms the regime establish and embed in institutions, religion, habits, socially-expected conduct, education and the generation of certain feelings; i.e., the prevailing ideology asserts its dominant role and pervades all areas of the lives of men and women with the aim of guaranteeing unity to the regime of accumulation of each time (Harvey, 2004).

This regime is made up of a set of regularities that ensure certain conditions of capitalist accumulation. A regime of accumulation is understood as "the mode of joint and compatible transformation of the norms governing production, distribution, and use. In other words, a regime of accumulation permits, during a long time period, adjusting the transformations of production conditions and the changes in consumption conditions" (Bustelo Gómez, 2003: 147). It relates to the stabilization of the relationships between the reproduction of consuming wage-earners and capital accumulation over a long period of time. Likewise, it implies the adaptation modes that occur between the transformation of production conditions and wage-earners' reproduction possibilities.

The existence, permanence and reproduction of a regime of accumulation 
persist as long as its reproduction scheme is coherent. For this to happen, a regime of accumulation must materialize that shapes the form of norms, habits, laws, regulation rules, etc., that ensure the unity of the process; that is to say, a convenient consistency of individual behavior with regard to the reproduction scheme.

This group of internalized rules and social processes is called a mode of regulation. The social and political regulation mode promotes, channels and limits individual behavior; it socializes heterogeneous behavior and it conditions the adjustment mechanisms of markets according to organizational rules and principles without which it cannot work.

In this sense, the educational system, training, persuasion, the inspiration behind certain social feelings - for instance, work ethics (Bauman, 1999) - play a role that is closely related to the formation of dominant ideologies that are fostered by the mass media, different branches of the state apparatus (as social policies), and religious and/or educational institutions (Skovdal et. al., 2013). Complementing Harvey's proposal, it can be stated that late capitalist societies should also deal with population masses which are not contained within the formal labor market (i.e. are either not working, or are working informally and are financially unable to guarantee their chances for reproduction (Offe, 1990)). Some of the mechanisms or regulation modes of the regime of accumulation that directly affect these sectors are social policies which not only allow for the mitigation of market 'flaws' by facilitating the giving out of goods (monetary or in kind) and services to populations to support their own reproduction, but they also operate as elements that embed in agents ways of looking and thinking about themselves in the world by transmitting certain world images (Scribano, 1997 and 2004).

\section{WORLD IMAGE AND POLICIES OF EMOTIONS}

Every critical reflection about the features of society implies much more than an immediate problematization of poverty - or whatever is expressed as a social problem at a particular time; it involves the thematization and awarding of significance to related problems as an explanation for unemployment, job insecurity, etc. World images constitute ways of classifying and explaining social phenomena, their causes, appropriate solutions, the place of agents, etc. which define how what is identified as a social problem and how it 'should' be handled. World images are closely related in one way or another to daily life; i.e. to the everyday knowledge that subjects share and which is always at hand to explain the social world. 
The way in which we conceive of and interpret reality always involves contact with phenomena, and, therefore, transformation of the said reality. At this point, analysis of social policies involves an effort to clarify and make explicit the different 'models' through which the said interventions are sustained. Departing from the world image that belongs to every intervention means making things happen and creating some kind of shape from an interpretative scheme which is assumed to be a representation of the reality that 'wants' to be modified. These perceptual frameworks cause different features of this world to come to light. From this perspective, the task of denaturing using an analysis of the world images of different explanations about social features and their intervention modes (social policies), means identifying from which place and under which suppositions social features are shaped. This means asking the question: which world we are trying to represent and intervene in?

Analysis of the world images of social policies allows us to understand those structures that support, in the form of suppositions, governmental intervention; it also allows us to give an account of the perceptive schemes from which said theory is constructed and, by exploring the shaping of these structures, to gain access to the degree of visibility they facilitate or prevent.

The aforementioned world images not only affect the design and implementation of social policies but also accumulate and reproduce in the perceptual schemes of the agents that are recipients of such images. This happens given that these world images imply a set of notions associated with the problematic situation concerning the solutions, the individuals responsible for them, and those who may be held accountable. From this point of view, they 'justify' some social practices but not others, thereby having a direct impact on a subject's capacity to act. On the one hand, this impact affects the material conditions for the production and reproduction of life (due to the transfer of good and services it implies), and on the other, it affects the perceptual schemes used to classify and divide the world which enable some behaviors but not others. As previously stated by Luna Zamora, "emotions reflect a process of organizing, selecting, and interpreting situations and events that we are handling. We do or we are able to do only what our linguistic repertoire and our social practices allow us to do" (Luna Zamora, 2007: 11). These practices happen to be the result of the sensations that, as a product of the social order in which they are embedded, are 'performed' by the prevailing regime. It is at this point that the complex weft between social policies and policies of emotions in current regimes becomes evident. If, as we have previously mentioned, social policies occupy a central place in guaranteeing the reproduction of the regime of accumulation, an examination 
of the policies of emotion allow us to begin to elucidate some of the regime's strategies - presented as the most intimate, individual and subjective - for its reproduction.

Perceptions, sensations and emotions constitute a triptych, the study of which allows us to better understand where sensibilities are grounded. Social agents experience the world through their bodies. What we know about the world is because of and through our bodies. A set of impressions has an impact on the 'exchanges' which occur within the socio-environmental context. Impressions of objects, phenomena, processes and other agents structure the perceptions that subjects accumulate and reproduce. In this way a naturalized mode of organizing the set of impressions obtained by an agent is formed.

This framework of impressions orders the sensations that agents 'obtain' about 'internal' and 'external' worlds, the 'social', 'subjective' and 'natural' worlds. This shaping consists of a dialectic tension between impression, perception and the results of these, which give sensations a 'sense' of surplus. In other words, it locates them closer or further from the aforementioned dialectics. Sensations, as a result and antecedent of perceptions, give way to emotions which can be seen as the manifestation of the action and effect of feelings. They are rooted in the states of feeling the world that build perceptions associated to socially constructed forms of sensations.

At the same time, organic and social senses also permit mobilization of that which seems unique and unrepeatable (such as individual sensations), and they carry out the 'unnoticed work' of the incorporation of the social - which has become emotion.

Consequently, the policy of bodies (i.e., the strategies that a society accepts in order to offer a response to the social availability of individuals) is a chapter - and not the least important chapter - in the structure-book of power. These strategies are tied and 'strengthened' by the policies of emotions that tend to regulate the construction of social sensibility.

Policies of emotions require regulating and make bearable the conditions under which order is produced and reproduced. In this context, we understand that social bearability mechanisms are structured around a set of practices that have become embodied and that are oriented towards a systematic avoidance of social conflict. Devices for the regulation of sensations consist of processes of selection, classification, and the elaboration of sociallydetermined and distributed perceptions. Regulation implies some sort of tension between senses, perception, and feelings that organize the special ways of 'appreciation-in-the-world' that classes and subjects possess. The mechanisms and devices identified are a practical and procedural hinge at which point emotions, bodies and narrations meet. 
The forms of sociability and experience are strained and twisted as if contained in a Mobius strip along with the sensibilities that arise from regulatory devices and the aforementioned mechanisms. Sociability becomes a way of explaining the ways in which agents live and coexist while interacting. Experience is a way to express the senses acquired by being-inbody with others as the result, on the one hand, of 'experiencing' the dialects that exist between the individual, social and subjective body and, on the other hand, the logics of the appropriation of body and social energies.

The system's social bearability mechanisms do not act either directly or explicitly as 'control attempts' or deeply as focal and punctual persuasion processes. They operate 'almost unnoticed' in the porosity of customs, in the frameworks of common sense, in the construction of sensations that seem most 'intimate' and 'unique' that every individual encounters as a social agent.

From this theoretical and epistemological context, it is possible to notice that there exists a set of links among social policies, world images, and the politics of emotions as key constituents in the regime of accumulation and the state interventions which occur to produce and reproduce the social order.

\section{WORLD IMAGES, SOCIAL POLICIES, POLICIES OF EMOTIONS, AND CONSUMPTION}

As we stated before, the world image held in social policies presupposes the appearance of a group of assumptions that define the limits and range of the social features of the time. This implies a demarcation and a definition of what at a particular point in time can be understood as a social problem. At the same time, it comprises a definition of a situation that contains a form of consensus about: a) which problems will be dealt with (or which will be omitted or will not be considered as a public problem); b) who the affected subjects are (and who they are not); c) what the identified needs and the ways of meeting them are (and which needs will not be of public concern); and d) who is responsible and may be held accountable for meeting these needs (and who is free from providing any kind of answer).

Analysis of the world images of social policies allows us to elucidate the socio-historical (and unnatural) character of not only the previouslymentioned problems as public but also of state or private answers, generated around the former. A regime of accumulation includes ways of managing the links between state and market, in which social policies occupy a central place by reducing levels of social conflict and guaranteeing their own reproduction in the long term. 
Currently, a basic feature of the regime of accumulation in peripheral societies is the direct link among social policies, the world images they imply, and consumption as the main goal and 'activity' on the part of the state.

According to this perspective, systemic reproduction is not only guaranteed by transfers of goods that decrease levels of social conflict but also by the production and reproduction of a certain regime of sensibility. Social policies are, from this perspective, part of the production framework of policies of the emotions. Through this path, there is a set of links between social policies, policies of the emotions and world images.

In close relation to the aforementioned, and as a metonymic expression of the phenomenon, a strong bond arises: statehood practices are connected to the practices of a society and normalized in immediate enjoyment through consumption. The explicit intention ${ }^{8}$ of the economic policies of current progressive democracies in Latin America is to achieve growth by increasing domestic consumption, partly through CCT Programs whose dissemination fulfills a fundamentally important function.

An example of this is the Asignación Universal por Hijo para Protección Social (Universal Child Allowance for Social Protection).

"These measures represent real steps forward in the aim of achieving the social inclusion of more Argentinians and, at the same time, they encourage demand, consumption and economic activity in our country" (ANSES, May, 2013 $3^{10}$ ).

"The problem is exactly the opposite: capitalism is consumption and we need to increase consumption, not adjust it. If there is no consumption, there will be no economic growth, there will be no development" (Speeches from Argentina's Presidency ${ }^{11}$ )

8 "[...] In this case, all direct policy beneficiaries highlight the positive influence of AUH (Asignación Universal por Hijo, Universal Child Allowance) in their lifestyles and in their attendance at school, especially as concerns growth in their consumption. If we understand that the appropriation of goods is an action that integrates and communicates (García Canclini, 1995, 1999), if we think that consumption is an activity through which we feel we belong, that we are part of networks or social groups, it is not possible to dissociate these practices from citizenship; being a citizen does not only have to do with voting or feeling represented by a political party, it also has to do with social and cultural practices that develop a sense of belonging and inclusion (Ministerio de Educación, 2011: 71-72).

9 Implemented by Decreto de Necesidad y Urgencia (Decree of Need and Urgency) 1602/09, at the end of 2009.

10 Available at: http://www.prensa.argentina.ar/2013/05/31/41229-la-anses-paga-desde-juniolas-asignaciones-con-aumento.php

11 Available at: http://www.presidencia.gov.ar/discursos/25918-almuerzo-en-el-council-de-lasamericas-palabras-de-la-presidenta-de-la-nacion 
Economic policies are 'virtuously' coordinated with a set of social policies - in particular with the CCT Programs mentioned before - in such a way that in the last decade millions of Latin Americans have been incorporated, through state assistance, into a society of consumption.

Consumption has become a fundamental link between the state and citizens. The strong link between economic policy, social policy, and the market becomes a restructuring factor and generates the conditions for the immediate enjoyment of, and, due to consumption, creation of experience. Policies of emotions are affected/penetrated by the consequences of dialectics that get updated in world images that are included in the social policies and sensibilities constructed by the above-mentioned policies of emotions.

Social policies create special sociabilities from world images. These are supported by and involve certain theories that, from the practices they generate, free up an individual to join/articulate in the market consumption experience offered by the state. In this way, consumption sensibilities are proposed/created concomitantly by the state and the market. The regime of accumulation can be said to be successful when it has efficiently created the conditions for capital reproduction.

Through the spread of consumption, millions of Latin American residents are now a part, as consumer citizens, of the current regime of accumulation. These features that the social policies acquire through the Conditional Cash Transfer Programs dispute the traditional divisions between the universalization and focalization of state interventions. As will be clarified in the next section, the massiveness of state interventions constitutes a fundamental feature of the way in which the regime produces, reproduces and persists over time, starting from certain policies of emotions based on immediate consumption.

\section{UNIVERSAL OR FOCALIZED: AN UNSETTLED DISPUTE? MASSIVENESS AND CONSUMPTION}

As we have previously stated, by the end of the 20th century, CCT Programs in Latin America had been developed as the best strategy for addressing poverty and maintaining the modes of articulation of citizens with the market and the state at the same time. These strategies for addressing poverty involved a focalization of the interventions that became massive in scale. It was precisely the removal of the distinction between focalized and universal policies that was one of the consequences of the massive scale of state assistance and also one of the factors that explains its effectiveness.

Nevertheless, the world image implied by said social policies did not 
emerge in the late-90s; on the contrary, it started developing from the 1980s in the light of contributions from the academic field, non-profit organizations, and multilateral credit organizations.

During the $80 \mathrm{~s}$ the sphere of competence of social policies as subsidiary in matters of poverty was constructed, consolidating the substitution of the idea of universality with the idea of focalization, leaving aside the focus on the causes and turning to the symptoms; this tendency was legitimated in the following decade (Sojo, 2007).

This way, throughout the 80 s, there was stronger emphasis on proposals that were in favor of 'focalizing' or 'focusing' social expenditure on poor populations in comparison to the 'universality' approach, thereby generating the dilemma between supporting universal or focalized policies. The decision relates to a change in understanding and implies the participation of economic and political elements which will determine the setting up and consolidation of a certain social structure; i.e., making society (Adelantado et. al, 2006).

In this context, universality essentially implies that the state should guarantee basic rights and distribute available resources among all of its citizens, but this does not preclude the recovery, by way of taxes, of funds from those with the highest incomes. In the 80 s the kind of 'universality' that had started with the Keynesian welfare state 'came to an end' along with its social policies that presented a world image of balance by means of state compensation for employees and employers.

Focalization, meanwhile, essentially derives from multilateral credit organizations, mainly the World Bank, which states that in order to reduce poverty it is necessary to design well-focalized programs (Sojo, 1990, 2003, 2007). The World Bank (Banco Mundial, 1988a: 13, cited in Sojo 1990) proposes focusing on vulnerable sectors and generalizing the focalization of public expenditure. To do this, every country should: a) contribute to solving the tax crisis of the state through social policies; b) concentrate social expenditure on the most vulnerable population groups through 'focalization' policies; c) limit the state's action in social policy matters; d) abandon universal policies; and, e) partly privatize social policies.

According to this perspective, and in a world with limited resources, focalizing appears to be the most attractive alternative for focusing benefits on those segments of the population 'who need it most'. The main idea refers to the selectivity of social expenditure, taking into account the fact that resource concentration increases the efficiency of transfers destined to fight poverty. Focalization also refers to assets as determining factors of income; they represent an objective group with specific characteristics and/or attributes, which is also internally homogeneous in relation to the effect that 
a certain set of political instruments can have on it. In this way, the concept does not focus on the causes but on the symptoms of poverty. Accordingly, the efficiency argument is convincing to critics of universal policies. It relates to how a society that recognizes those with fewer chances and worries about equity expresses itself.

During the 90s, social policies in Latin America and Argentina underwent a transformation in their three operational modes: labor, social security, and welfare. In relation to the first, the state left aside its role as guardian and regulator of contractual relationships ${ }^{12}$; as to social security policies, it opted for the privatization of employment-injury insurance and a large welfare system. As for the specific field of welfare policies, meaning transfers of money or goods to sectors of society which lack the opportunity to meet their needs through the labor market, there has been a twin process of decentralization and focalization. In this way, over the last three decades state functions have been redefined and a new perspective on social policies has been consolidated, based on making budget reductions, returning to the old system of administrative decentralization, the focalization of welfare programs in comparison to the universality of the welfare state, and a constant appeal to civil society (Halperin et. al., 2008).

Rozenwurcel and Vázquez declare that "in 1996 the first massive income transfer program was created: Plan Trabajar ('Working Plan'). Its aim was to provide employment to unemployed people who were not covered by unemployment insurance. The program provided a non-contributory sum of AR $\$ 200^{13}$ for a six-month period. Also in 2000, the Plan de Emergencia Laboral ('Work Emergency Plan') was created, focused on a group of provinces with the aim of training and employing workers with employability problems" (2008: 253); then after the 2001/2002 crisis, Plan Jefes y Jefas de Hogar Desocupados (Program for Unemployed Male and Female Heads of Households, PJyJHD) became one of the emblematic programs with respect to its massive scope - reaching 2 million beneficiaries, according to official data (Documento Institucional MDS 2004, 2010). At that time PJyJHD beneficiaries were classified based on their employability. Those considered unemployable were included in the Plan Nacional Familias por la Inclusión Social ('Households for Social Inclusion Program') the immediate predecessor of the Universal Child Allowance This CCT Program, along the lines of the

12 Due to a combination of general system deregulation, the development of new and flexible forms of hiring and emergency interventions in the shape of active employment policies, among others.

13 Equal to \$200 US Dollars at the official exchange rate from 1996. 
others implemented in the area, has become, historically speaking, the most important one in Argentina not only due to the number of beneficiaries its covers (3.5 million), but also due to the budget items assigned to it. It is necessary to take into account that one of its most remarkable features is the 'massive' introduction of a series of beneficiaries to social programs.

As a result, there is a new meaning of 'massive' - meaning 'for many'; an adjective that means 'very large' and which obscures the fact that it does not apply to everyone. The new concept keeps at bay the debate about focalization vs. universality, leaving clear evidence of the need to 'serve the largest number of people'.

In the context of the present discussion, it is possible to see how 'the massive' is part of a policy of emotions which considers the construction of a world image to be a basic component of the cognitive-emotional suppositions of a particular theoretical horizon, and of the intervention into present social policies, at least in Argentina.

In other words, massiveness implies the assumption of a normalized society through biological/environmental 'adjustments' of agents who are thought of as people who have been excluded from 'development' and who can contribute to mending the defects of the market and the state through consumption. Massiveness reconstructs the risks of an environment likely to be managed through increasing levels of interventionism, making - ceteris paribus - major qualitative modifications to the expulsion spheres created by capitalist expansion.

In the same way, massive interventions imply the existence of subjects that - being 'outside the system' - become, through CCT Programs, individuals whose passivity is taken for granted in the management of personal and bank transfers.

The main supposition of the 'massive' approach to social policies is uncritical acceptance of the idea that societies which act in a constantly expanding and differentiating time/space can be considered to be undergoing 'development'.

In this framework, adaptation and consumption are the two privileged resources of massiveness in terms of action coordination and subject differentiation, providing a fundamental basis for the configuration of subjectivity.

As one of the goals of the CCT Programs, massiveness becomes one of the elements in the world image and contributes to the development of a politics of emotions. 


\section{CONCLUSIONS}

According to the observations made so far, the sociabilities, life experiences and sensibilities of millions of subjects are constructed in and through social policies which involve certain world images and which act to develop the policies of emotions through a 'massiveness' approach to consumption.

Over the development of this paper we have seen that the regime of accumulation requires social policies to last in time. Firstly, because social policies reduce the levels of social conflict associated with people who live in conditions of deprivation, and secondly, because they allow for their reproduction under normal conditions. Therefore, they are a key component of present peripheral capitalisms.

As to their role in reducing social conflict, they operate through at least two mechanisms. One of them is the increase, via a monetary injection, in the consumption level of the beneficiaries of (for example), what have come to be known as Conditional Cash Transfer Programs. The other one implies an alteration of the ways in which subjects perceive the world around them. Here is where the notion of a world image acquires all its centrality through its power to make up and be made up by perceptions and world division schemes that cause some features to come to light while others are hidden.

This world image contained in social policies works as a perceptual scheme that enables only some emotional behaviors. The sociology of the body and emotions contributes to the field of analysis of social policies by allowing the reconstruction of the regime of sensibility that a governmental intervention is involved in by establishing not only which needs will be recognized, but also which demands will be legitimated, what the solutions will be, who will be responsible and who will be held accountable.

We have also seen how the massiveness of governmental interventions into populations, sustained in world images, inhabits/creates a set of sociabilities and experiences linked to individuals who are thought to be able to 'mend' the defects of the market and the state through consumption, based on their subjectivity which, by definition, is considered to be 'passive'.

Cash Transfer Programs have spread throughout the Global South as central constituents of social policies that focus on poverty. Such policies have developed into massive programs with large amounts of recipients and budgets and have had a direct impact on the consumption of poor families without affecting the precarious structural conditions in which they live.

The links between sociability, life experiences and sensibility that occur in the relationship between massive social policies and policies of emotions have been adapted and upscaled to a world of consumption; a fact that, in 
short, implies the triumph of capital reproduction at a global level.

The massiveness of Cash Transfer Programs, which are general to the region but also specific to Argentina, accounts not only for their development as the preferred politics of the state (and international organizations) regarding social matters, but also for their particularly massive effect on bodies and emotions in conditions of poverty. Through managing bodies/emotions, such effects can be identified as part of the framework of the reproduction of the capitalist regime of accumulation.

\section{BIBLIOGRAPHY}

Adelantado, José \& Scherer, Elenise (2006), ¿Dificultan las políticas sociales focalizadas el desarrollo de la democracia en América Latina?" Ponencia presentada en el XI Congreso Internacional del CLAD sobre la Reforma del Estado y la Administración Pública" 7-10 nov. Documento Libre. Ciudad de Guatemala. http://www.aecpa.es/uploads/files/congresos/congreso_08/area6/GT18/ADELANTADO-JOSE.pdf (Access 15/09/2014).

Boyer, Robert \& Saillard, Yves (1998), Teoría de la Regulación: estado de los conocimientos. Vol. I, II y III. La Plata, Eudeba.

Bustelo Gómez, Pablo (2003), "Enfoque de la regulación y Economía Política Internacional ¿Paradigmas Convergentes?” Revista de Economía Mundial. No.8, 2003, pp143 173.

Cena, Rebeca \& Chahbenderian, Florencia (2012), "El crédito y el consumo como "condiciones" de contentar y contener a las poblaciones expulsadas", in Boletín Onteaiken $\mathrm{N}^{\circ} 14$, "Felicidad y creatividad: cuerpos contentos y en movimiento". http://onteaiken.com.ar/ver/boletin14/1-4.pdf (Access 15/09/2014).

Corak, Miles, Lietz, Christine \& Sutherland, Holly (2005), "The impact of tax and transfer systems on children in the European Union", Innocenti Working Paper 2005-04, Florence, UNICEF Innocenti Research Centre.

De Sena, Angélica (2011), "Promoción de Microemprendimientos y Políticas Sociales: ¿Universalidad, Focalización o Masividad?, una discusión no acabada”. Pensamento Plural 8, Pelotas-Brasil, pp. 5-36.

Halperin Weisburd, Leopoldo; Labiaguerre, Juan Antonio; Delpech, Cecilia; González, Marita, Horen, Berta; Villadeamigo, José; Siffredi, Liliana \& Muller, Guillermo (2008), "Políticas sociales en la Argentina: entre la ciudadanía plena y el asistencialismo focalizado en la contención del pauperismo". Cuaderno del CEPED No 10. Buenos Aires, Argentina, Facultad de Ciencias Económicas, UBA. Harvey, David (2004), "Introducción" in La Condición de la Posmodernidad. Investigación sobre los orígenes del cambio cultural. Buenos Aires. Amorrortu, pp. 143-146.

Hochschild, Arlie (2011), "La elaboración del sentimiento", in La mercantilización de la vida íntima. Apuntes de la casa y el trabajo, Bs. As., Katz, pp. 129-154. 
Luna Zamora, Rogelio (2007), "Emociones y subjetividades. Continuidades y discontinuidades en los modelos culturales" in Luna Zamora, Rogelio y Scribano, Adrián (Comp.) Contigo Aprendí...Estudios Sociales de las Emociones. Córdoba, CEA-CONICET-Universidad Nacional de Córdoba-CUSCH- Universidad de Guadalajara, pp. 233-247.

Ministerio de Educación (2011), “Análisis y evaluación de los aspectos educativos de la Asignación Universal por Hijo" http://observatorio.anses.gob.ar/archivos/ documentos/OBS\%20-\%20000174\%20-\%20An\%C3\%Allisis\%20y\%20 evaluaci $\%$ C3\%B3n\%20de\%20los $\% 20$ aspectos $\% 20$ educativos $\% 20$ de $\% 20$ la $\% 20$ AUH.pdf (Access 15/09/2014)

Montanari, Ingallil (2000), From family wage to marriage subsidy and child benefits: controversy and consensus in the development of family support', Journal of European Social Policy, 10, 4, pp. 307-333.

Offe, Claus (1990), "La Política Social y la Teoría del Estado" in Contradicciones en el Estado de bienestar. México. Alianza Editorial, pp. 72-104.

Rozenwurcel, Guillermo \& Vázquez, Claudia (2008), "Argentina modelo XXI: inestabilidad macroeconómica, empobrecimiento sostenido y políticas sociales", en Cruces, Guillermo; Moreno, Juan; Ringold, Dena; Rofman, Rafael (Edit.) Los programas sociales en Argentina hacia el Bicentenario. Bs. As. Banco Mundial, pp. 235-272.

Scribano, Adrián (1997), "Post-Empirismo y Rol Normativo de la Filosofía de las Ciencias Sociales" in Adrián Scribano (Comp.) Red de Filosofía y Teoría Social. Catamarca, SEDECyT. UNCa, pp. 231-252.

Scribano, Adrián (2004a), Combatiendo Fantasmas. Chile, Universidad de Chile, Facultad de Ciencias Sociales.

Scribano, Adrián (2012), Teorías sociales del Sur: Una mirada post-independentista. Buenos Aires, ESEditora.

Scribano, Adrián (2013a), "La religión neo-colonial como la forma actual de la economía política de la moral" De prácticas y discursos cuadernos de ciencias sociales, Año 2, número 2. Centro de Estudios Sociales (CES) Universidad Nacional del Nordeste (UNNE).

Scribano, Adrián (2013b), "Una aproximación conceptual a la moral del disfrute Normalización, consumo y espectáculo" RBSE-Revista Brasileira de Sociologia da Emoção, v. 12, n. 36, pp. 738-750, http://www.cchla.ufpb.br/rbse/ScribanoDos. $p d f$ (Access 15/09/2014)

Scribano Adrián \& Angélica De Sena (2014) “Consumo Compensatorio: ¿Una nueva forma de constituir sensibilidades desde el Estado?” in Revista Latinoamericana de Estudios sobre Cuerpos, Emocioes y Sociedad, N 15, 6 http://www.relaces.com.ar/ index.php/relaces/article/view/335/216 (Access 24/06/2015)

Skovdal, Morten, Robertson, Laura, Mushati, Phyllis, Dumba, Lovemore, Sherr, Lorraine, Nyamukapa, Constance \& Gregson, Simon (2013), "Acceptability of conditions in a community-led cash transfer programme for orphaned and vulnerable children in Zimbabwe". Health policy and planning. pp. 1-9.

Sojo, Ana (1990), "Naturaleza y selectividad de la política social", Revista de la 
CEPAL, No 41, Santiago de Chile, pp. 183-199.

Sojo, Ana (2003), "Vulnerabilidad social, aseguramiento y diversificación de riesgos en América Latina y el Caribe" in Revista de la CEPAL N" 80, pp 121-140.

Sojo, Ana (2007), "La trayectoria del vínculo entre políticas selectivas contra la pobreza y políticas sectoriales" in Revista de la CEPAL Na 91, pp 111-131.

Stampini, Marco \& Tornarolli, Leopoldo (2012), "The growth of conditional cash transfers in Latin America and the Caribbean: did they go too far?" InterAmerican Development Bank Social Sector Social Protection and Health Division Policy Brief No. Idb-Pb-185 http://idbdocs.iadb.org/wsdocs/getdocument. aspx?docnum $=37306295$ (Access 15/09/2014). 
